\title{
The role of selected parental and perinatal factors in the future mobility of children with myelomeningocele
}

\section{Znaczenie wybranych czynników rodzicielskich i okołoporodowych dla przyszłej czynności motorycznej dzieci z przepukliną oponowo-rdzeniową}

AGATA KORZENIECKA-KOZERSKA ${ }^{\text {A-G }}$, JOANNA BAGIŃSKA ${ }^{\text {B, D, E }, ~ A L I C J A ~ L I S Z E W S K A ~}{ }^{\text {B, D-F }}$, TADEUSZ POROWSKI ${ }^{A, C, G}$

Department of Pediatrics and Nephrology, Medical University of Bialystok

A - Study Design, B - Data Collection, C - Statistical Analysis, D - Data Interpretation, E - Manuscript Preparation, $\mathbf{F}$ - Literature Search, $\mathbf{G}$ - Funds Collection

Summary Background. Myelomenigocele $(\mathrm{MMC})$ is the most severe form of spina bifida, caused by genetic and environmental components; it has many serious complications in a patient's future life, where dysfunctional mobility is one of the most troublesome.

Objectives. The aim of our study was to explore the role of selected factors: parental and perinatal in children with myelomenigocele and correlate them with their future motor function.

Material and methods. This retrospective analysis was based on 95 births that occurred from 1985 to 2013. Clinical data were collected using medical records and supplemented by a questionnaire for parents. Standard deviation of WHO scores (Z-scores) for weight, length, and body mass index (BMI) at birth were calculated. Hoffer's scale was used to assess MMC children's motor function. Results. There were no statistically significant differences between 53 girls and 42 boys who were enrolled in the study, excluding the month of conception. The tested parameters did not vary substantially according to maternal age. Maternal age correlated positively with paternal age at conception, birth order, and stillbirth rate. Mode of delivery was strongly associated with Apgar scale and birth weight. Apgar score, birth length, and thus WHO Z-score for length-for-age had positive correlations with future mobility of MMC children.

Conclusions. 1. Perinatal factors have a significant effect on children's physical activity. 2. There is no clinical evidence that cesarean section improves early neurological outcome of MMC infants. 3. Parental factors, particularly maternal age, do not determine the future mobility of children with myelomeningocele.

Key words: myelomeningocele, parental factors, perinatal factors, motor function.

Streszczenie Wstęp. Przepuklina oponowo-rdzeniowa jest najcięższą postacią rozszczepu kręgosłupa, której przyczyny mogą być genetyczne i środowiskowe; daje wiele ciężkich powikłań w przyszłym życiu pacjentów, wśród których trudności w poruszaniu się są jednymi z najbardziej uciążliwych.

Cel pracy. Ocena wybranych czynników: rodzicielskich i okołoporodowych i ich korelacja z czynnością motoryczną dzieci z przepukliną oponowo-rdzeniowa.

Materiał i metody. Retrospektywnej analizie poddano 95 historii pacjentów objętych opieką w latach od 1985 do 2013 . Dane zostały uzupełnione wywiadem od rodziców dzieci. Dla takich parametrów jak: ciężar ciała, długość oraz wskaźnik masy ciała (BMI) w momencie urodzenia wyliczono odchylenia standardowe według WHO. Do oceny czynności motorycznej użyto skali Hoffera.

Wyniki. Nie wykazano istotnych statystycznie różnic między 53 dziewczynkami i 42 chłopcami, z wyjątkiem miesiąca urodzenia. Wartości badanych parametrów nie różniły się istotnie w zależności od wieku matki. Wiek matki korelował pozytywnie z wiekiem ojca w momencie poczęcia dziecka, rodzajem porodu i częstością poronień. Rodzaj porodu korelował ze skalą Apgar i masą urodzeniową ciała. Skala Apgar, długość urodzeniowa ciała i WHO Z-score dla długości wykazały pozytywne korelacje z późniejszą czynnością motoryczną dzieci z przepukliną oponowo-rdzeniową.

Wnioski. 1. Czynniki okołoporodowe mogą mieć znaczący wpływ na aktywność fizyczna dzieci z przepuklina oponowo-rdzeniową. 2. Nie ma dowodów na to, że cięcie cesarskie poprawia wczesną neurologiczną ocenę dzieci z przepukliną oponowo-rdzeniową. 3. Czynniki rodzicielskie, szczególnie wiek matki, nie wpływają na przyszłą aktywność fizyczną dzieci z przepukliną oponowo-rdzeniową.

Słowa kluczowe: meningomyelocele, czynniki rodzicielskie, czynniki okołoporodowe, czynności motoryczne.

\section{Background}

Spinal dysraphism (SD) refers to a variety of congenital malformations caused by neural tube defects (NTDs) during different stages of embryogenesis. The incomplete closure of the spinal cord and vertebral column begins at approxi- mately 18 days and is complete by 35 days gestation. SD can be clinically categorized into open spinal dysraphism (OSD) and closed spinal dysraphism (CSD) [1]. The most common form of OSD in newborns is myelomeningocele (MMC), classified as open spina bifida. The estimated prevalence of MMC is $1 / 700$ live births. MMC remains the most 
severe form of neural tube defects, involving dysfunctions of many organs and structures [2].

Children with MMC have a decreased sensory ability of the extremities, affecting mobility and independence. Their quality of life and future mobility depend on the level of spinal lesion. It has frequently been noted that high-level paralysis precludes community ambulation. The higher the neurological lesion level, the more medical complications and worse functional health were observed [3].

The etiology of MMC is largely incomplete. It has been suggested to have a multifactorial origin in which genetic, lifestyle, and environmental factors appear to be involved [4-6]. However, not only the types of factors but also the time when they appear should be taken into consideration. According to many studies, human development rates are highest during the first trimester of pregnancy. It seems to be the most crucial phase of fetal development. The question is if earlier and later time periods may be essential too. Do selected factors at the beginning and end of pregnancy have an effect? In addition to the beginning of pregnancy, is the moment of delivery essential too? Risk of several disorders may depend on paternal or maternal age and thus increase with increasing birth rank. For example, the risk of an aneuploid zygote, such as trisomy 21 , increases significantly with maternal age, while achondroplasia increases with paternal age [7].

\section{Objectives}

Hence, the aim of our study was to explore the role of parental and perinatal factors in MMC children and correlate them with their future motor function.

\section{Material and methods}

This retrospective analysis was based on 95 births that occurred from 1985 to 2013. All enrolled patients were treated in a tertiary care referral hospital in Bialystok. All MMC patients' clinical data were collected from a questionnaire for parents and the children's medical records. The question- naire included such information as: parental age, birth order, history of pregnancy complications (stillbirth, fetal loss, preterm labor, bleedings), gestational age, delivery mode, Apgar scale, and birth weight and length. Standard deviation WHO Z-scores for weight, length and body mass index (BMI) at birth were calculated. The ambulatory function of MMC patients was defined according to Hoffer's scale (HS) using the 4 categories of community: $1 \mathrm{HS}$ - nonambulator, $2 \mathrm{HS}$ - nonfunctional ambulator, $3 \mathrm{HS}$ - household walkers, $4 \mathrm{HS}$ - community walkers [8]. The lesion level in MMC patients was reported intraoperatively and radiologically and scored from 1 to 3 (1 - thoracolumbar, 2 - lumbosacral, 3 - sacral lesion). Additionally, all parameters were analyzed according to the period of conception and birth. We divided months of the year into two periods: winter (Oct. to Mar.) and summer (Apr. to Sept.).

Statistical analysis was performed using Statistica 10.0 (StatSoft Inc, Tulsa, OK, USA). All studied parameters were analyzed using nonparametric tests: Mann-Whitney and ANOVA analysis. Correlations were assessed by the Spearman test. Values of $p<0.05$ were considered significant.

Patients and their parents were enrolled into the study after obtaining informed consent.

The study protocol was approved by the Ethics Committee, Medical University of Bialystok, and was conducted in accordance with the Declaration of Helsinki.

\section{Results}

The characteristics of the studied patients are presented in Table 1. There were no statistically significant differences in the studied parameters between girls and boys, excluding the month of conception. We found that the highest prevalence of $\mathrm{MMC}$ boys were conceived during the winter period, whereas most MMC girls were conceived during the summer period. A positive correlation between the sex of MMC children and the month of conception $(r=0.213 ; p<0$. 05) was found. Most MMC children $(62 / 95 ; 65 \%)$ were born in the

\begin{tabular}{|c|c|c|c|c|}
\hline & MMC Patients & MMC Girls & MMC Boys & Comparison \\
\hline & \multicolumn{4}{|c|}{ (median, minimum-maximum) } \\
\hline Female/Male $n(\%)$ & 95 & $53(56 \%)$ & $42(44 \%)$ & \\
\hline \multicolumn{5}{|l|}{ Parental factors } \\
\hline Maternal age & $27(18.5-41.5)$ & $28.3(19-41.5)$ & $27(18.5-41)$ & 0.68 \\
\hline Paternal age & $32.3(18-48.5)$ & $32.6(18-48.5)$ & $32.2(19.5-44.5)$ & 0.59 \\
\hline Month at conception & $7(1-12)$ & $7(1-12)$ & $7.5(1-12)$ & 0.5 \\
\hline $\begin{array}{l}\text { Conceived time summer/win- } \\
\text { ter } n(\%)\end{array}$ & $43(45) / 52(55)$ & $29(55) / 24(45)$ & $14(33) / 28(67)$ & $0.04^{*}$ \\
\hline Birth order & $2(1-8)$ & $2(1-6)$ & $2(1-8)$ & 0.93 \\
\hline \multicolumn{5}{|l|}{ Perinatal factors } \\
\hline Gestational age & $40(32-43)$ & $40(32-42)$ & $40(32-43)$ & 0.92 \\
\hline Birth weight $(\mathrm{kg})$ & $3.15(1.2-4.8)$ & $3.17(1.7-4.3)$ & $3.12(1.2-4.8)$ & 0.67 \\
\hline Birth length $(\mathrm{cm})$ & $54(40-61)$ & $54(43-61)$ & $54(40-60)$ & 0.32 \\
\hline Delivery $n ; \mathrm{C} / \mathrm{V}$ & $80 ; 7 / 33$ & $46 ; 25 / 21$ & $34 ; 20 / 14$ & 0.64 \\
\hline Apgar scale & $8(1-10)$ & $8(3-10)$ & $8(1-10)$ & 0.7 \\
\hline Z-score WHO weight & $-0.28(-5.3-3.8)$ & $-0.08(-3.8-2.8)$ & $-0.45(-5.3 ; 3.8)$ & 0.85 \\
\hline Z-score WHO length & $2.28(-5.5-6.8)$ & $2.8(-4.6 ; 6.8)$ & $2.28(-5.5 ; 5.6)$ & 0.2 \\
\hline BMI & $11.2(4.3-19.3)$ & $11.12(7.5-19.3)$ & $11.3(4.3-15)$ & 0.83 \\
\hline
\end{tabular}

$\mathrm{C}$ - cesarean, $\mathrm{V}$ - vaginal, BMI - body mass index, $* p<0.05$. 
last 10 years and there were no differences in all parameters between infants born during the two assessed periods.

Median maternal age was $27(18.5-41)$ years. Most mothers $(53 / 84 ; 63 \%)$ were younger than 30 years old at conception. Median paternal age was $32.3(18-48.5)$ years. The majority of MMC children 37/92 (40.22\%) were born from the first pregnancy, 26/92 (28.26\%) from the second, $10 / 92(10.87 \%)$ from the third, $9 / 93(9.78 \%)$ from the fourth, and $8 / 92(8.7 \%)$ from the fifth or later pregnancy.

Additionally, we found that $8 / 84(9.5 \%)$ mothers had a history of miscarriages, and 15/81 (19\%) had other complications. Maternal age correlated positively with birth order $(r=0.547$; $p<0.05)$, the presence of miscarriages $(r=0.238 ; p<0.05)$, and paternal age $(r=0.868 ; p<0.05)$. Children whose mothers were younger, differed from children whose mothers were older in the order of deliveries and paternal age. Birth order correlated positively with maternal age $(r=0.566$; $p<0.05)$, paternal age $(r=0.785 ; p<0.05)$, the presence of miscarriages $(r=0.418 ; p<0.05)$ and delivery mode $(r=0.279 ; p<0.05)$.

The values of all analyzed MMC children's perinatal factors are included in Table 1 . There were no differences between boys and girls between the studied parameters. Detailed data of children born by cesarean section and vaginal delivery are shown in Table 2.

Additionally, we found a positive correlation between birth weight and birth length $(r=0.598 ; p<0.05)$. These parameters positively correlated with gestational age $(r=0.498$; $r=0.334$; respectively; $p<0.05)$ and Apgar scale $(r=0.256$; $r=0.425$; respectively; $p<0.05)$. Birth weight positively correlated with mode of delivery $(r=0.283 ; p<0.05)$; whereas birth length positively correlated with month of conception $(r=0.258 ; p<0.05)$, complicated pregnancy $(r=0.369$; $p<0.05)$, Hoffer's scale $(r=0.405 ; p<0.05)$, and level of lesion $(r=0.429 ; p<0.05)$. Apgar scale positively correlated with gestational age $(r=0.259 ; p<0.05)$, mode of delivery $(r=0.309 ; p<0.05)$, Hoffer's scale $(r=0.270 ; p<0.05)$, birth weight $(r=0.256 ; p<0.05)$, and birth length $(r=0.425$; $p<0.05)$.

The levels of spinal cord lesion and the characteristics of the different patients' groups classified by HS are shown in Table 3.

\begin{tabular}{|l|l|l|l|l|l|}
\hline \multirow{2}{*}{ Table 2. The perinatal parameters in MMC children depending on the type of delivery } \\
\cline { 2 - 7 } & \multicolumn{2}{|l|}{ Cesarean delivery } & \multicolumn{2}{l|}{ Vaginal delivery } \\
\cline { 2 - 6 } & $n$ & median (minimum-maximum) & $n$ & median (minimum-maximum) \\
\hline Gestational age & 44 & $38(33-43)$ & 32 & $40(32-42)$ \\
\hline Birth order & 47 & $2(1-6)$ & 33 & $2(1-8)$ \\
\hline Apgar scale & 46 & $8(1-10)$ & 32 & $9(1-10)$ \\
\hline Birth weight $(k g)$ & 45 & $3.0(1.2-4.8)$ & 32 & $3.3(1.9-4.6)$ \\
\hline Z-score WHO weight & 45 & $-0.5(-5.3-3.8)$ & 26 & $0.25(-3.5-3.3)$ \\
\hline Z-score WHO length & 38 & $2.27(-5.5-6.8)$ & 26 & $2.27(-3.8-5.6)$ \\
\hline
\end{tabular}

$n$ - number of patients.

\begin{tabular}{|c|c|c|c|c|}
\hline & HS1 & HS2 & HS3 & HS4 \\
\hline$n$ & 52 & 15 & 12 & 16 \\
\hline $\mathrm{F} / \mathrm{M} n(\%)$ & $29(58) / 23(42)$ & $7(47) / 8(53)$ & $9(73) / 3(27)$ & $8(50) / 8(50)$ \\
\hline \multirow[t]{2}{*}{ Lesion level Th-L/L-S/S } & $31 / 21 / 0$ & $0 / 13 / 2$ & $0 / 11 / 1$ & $0 / 8 / 6$ \\
\hline & \multicolumn{4}{|c|}{ Median (minimum-maximum) } \\
\hline \multicolumn{5}{|l|}{ Parental factors } \\
\hline Maternal age & $25(19-41)$ & $27(20-41)$ & $31(22.7-41.5)$ & $28.9(18.5-36.9)$ \\
\hline Paternal age & $32.3(18-36.8)$ & $30.8(23-44.6)$ & $32(24.08-48.5)$ & $33.3(19.5-45.92)$ \\
\hline Conception time & $8(1-12)$ & $7(1-11)$ & $8(1-12)$ & $5(1-12)$ \\
\hline Conceived time Sum/Wint $n(\%)$ & $29(58) / 21(42)$ & $9(60) / 6(40)$ & $6(55) / 5(45)$ & $6(43) / 8(57)$ \\
\hline Birth order & $2(1-8)$ & $1(1-6)$ & $2(1-4)$ & $2(1-6)$ \\
\hline \multicolumn{5}{|l|}{ Perinatal factors } \\
\hline Gestational age & $40(32-42)$ & $38(33-43)$ & $40(35-41)$ & $40(33-41)$ \\
\hline Birth weight $(\mathrm{kg})$ & $3(1.68-4.8)$ & $3.04(1.2-3.9)$ & $3.36(2.8-4.3)$ & $3.2(2.3-4.2)$ \\
\hline Birth length (cm) & $52(40-58)$ & $54.5(49-58)$ & $54(50-61)$ & $55(52-61)$ \\
\hline $\begin{array}{l}\text { Delivery } n(\%) ; \\
\text { C/V }\end{array}$ & $\begin{array}{l}43 ; \\
24(56) / 19(44)\end{array}$ & $\begin{array}{l}12 ; \\
10(83) / 2(17)\end{array}$ & $\begin{array}{l}9 ; \\
4(44) / 5(56)\end{array}$ & $\begin{array}{l}12 ; \\
5(42) / 7(58)\end{array}$ \\
\hline Apgar scale & $8(1-10)$ & $8(1-10)$ & $8.5(6-10)$ & $9(6-10)$ \\
\hline Z-score WHO W & $-0.5(-3.8-3.8)$ & $-0.5(5.3-1.6)$ & $0.38(-1.0-2.8)$ & $0.0(-2.3-2.5)$ \\
\hline Z-score WHO L & $1.6(-5.5-4.5)$ & $2.8(-0.5-4.5)$ & $2.3(-4.6-6.8)$ & $3.4(1.7-6.8)$ \\
\hline BMI & $11.4(8.1-15.7)$ & $9.6(4.3-11.8)$ & $11.8(9.6-19.3)$ & $10.6(8.2-12.5)$ \\
\hline
\end{tabular}

$n$ - number, $\mathrm{F}$ - female, $\mathrm{M}$ - male, Sum - summer, Wint - winter, $\mathrm{W}$ - weight, $\mathrm{L}$ - length; the lesion level: Th- $\mathrm{L}-\mathrm{thoracolumbar}, \mathrm{L}-\mathrm{S}$ - lumbosacral, S- sacral. 
We found a positive correlation between $\mathrm{HS}$ and the level of lesion $(r=0.701 ; p<0.05)$. Both parameters correlated positively with birth length $(r=0.405 ; p=0.429$; respectively; $p<0.05)$ and WHO Z-score for length-for-age $(r=0.364$; $r=0.402$; respectively; $p<0.05)$. Additionally, HS was also statistically significant positively correlated with Apgar scale $(r=0.270)$ and history of miscarriages $(r=0.241)$.

Maternal and paternal age, month of conception, and birth order did not vary significantly between HS groups $\left(\chi^{2}=5.76 ; \chi^{2}=0.12 ; \chi^{2}=0.48 ; p=0.92 ; \chi^{2}=1.74 ; p=0.63\right.$; $\chi^{2}=0.73 ; p=0.87$; respectively). The lowest birth weights and lengths were observed in $1 \mathrm{HS}$ group; whereas the highest birth weights and lengths were observed in $3 \mathrm{HS}$ and $4 \mathrm{HS}$. Lower birth weights and lengths were observed in MMC children with the worst future activity. The differences were statistically significant for birth weight $\left(\chi^{2}=9.69 ; p=0.02\right)$. The longest children were in $4 \mathrm{HS}$ and the shortest in $1 \mathrm{HS}$ groups. However, the differences were not statistically significant $\left(\chi^{2}=5.66 ; p=0.13\right)$.

The differences in birth weight and birth length between HS groups are shown in Figure 1 and Figure 2.

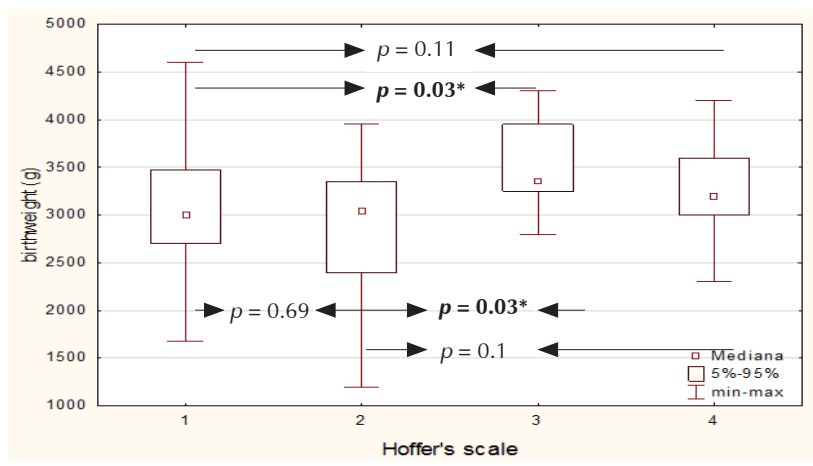

Figure 1. Comparisons of birth weight values between various Hoffer's scale groups in MMC children; ${ }^{*} p<0.05$

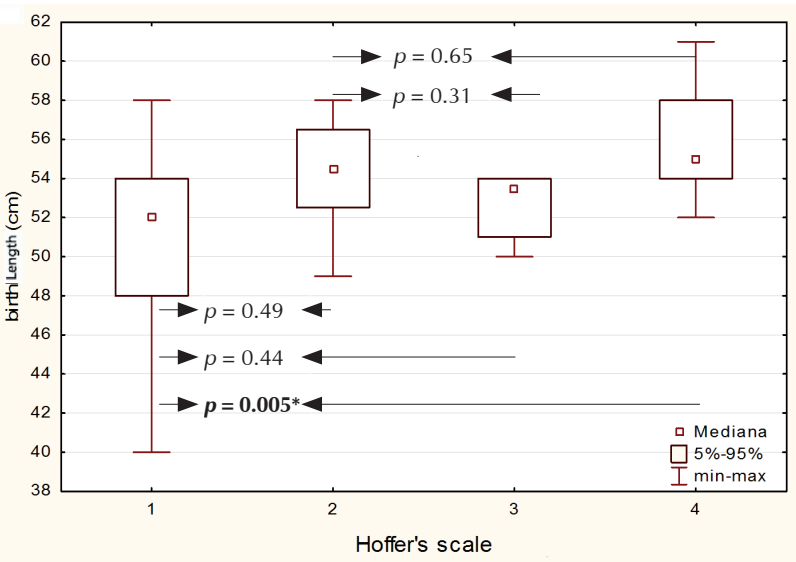

Figure 2. Comparisons of birth length values between various Hoffer's scale groups in MMC children; $*<0.05$

The most HS1 and HS2 MMC children were born by cesarean section (CS) (34/55 children, 62\%); whereas more children from the $3 \mathrm{HS}$ and $4 \mathrm{HS}$ groups were born by vaginal delivery (12/21 children, 57\%).

The Apgar scale differed between the four studied groups and the difference was statistically significant $\left(\chi^{2}=9.74\right.$; $p=0.02)$. The highest median value was observed in the $3 \mathrm{HS}$ and $4 \mathrm{HS}$ groups (8.5 (6-10); 9 (6-10), respectively). There were no differences in gestational age in the studied groups $\left(\chi^{2}=0.53 ; p=0.91\right)$.

\section{Discussion}

Our study was the first in our region - north-eastern Poland - focusing on perinatal and parental factors in children with myelomeningocele (MMC). Our intention was to verify if those factors correlate with future physical activity of MMC children.

Epidemiological and laboratory studies have cited a variety of potential causes for MMC. They show that neural tube defects (NTDs) are caused by the interplay of multiple genes, along with the interaction of genes with their environment. If genetics plays an important role in $M M C$, we aimed to explore the role of parental factors in the occurrence of $M M C$ in infants in our region.

It is well established that both lower and high maternal age and late birth order have contributed to some birth defects [9-16]. Nonetheless, little data is available for children with meningomyelocele (MMC) considering future activity. Our analyses did not confirm a relation between the prevalence of MMC and parental factors. Parental age, birth order, or month of conception did not play a significant role in the future mobility of MMC children.

However, perinatal factors and level of lesion had a significant effect on MMC children's physical activity. In our study, like in others, the level of mobility correlated with spinal lesion level. Pauly and Cremer [3] found a major portion of community and household walkers according to Hoffer's criteria in the lower level (sacral and lumbosacral level) lesion groups, whereas the portion of nonwalkers was far lower than the groups of thoracolumbar and thoracic lesions. Our analyses also confirmed that a higher level of neurological lesion caused worse mobility functions.

There are few studies focused on finding relations between mode of delivery and subsequent motor function in infants with MMC. The benefits and risks of different modes of delivery are controversial. Studies performed in the $1980 \mathrm{~s}$ [17] recommended prelabor cesarean section (CS) to preserve exposed spinal neural elements of infants with MMC. In 1991, Luthy et al. [18] demonstrated that MMC children who were exposed to the forces of labor were 2.2 times more likely to have severe paralysis than those delivered by prelabor CS. It has been proposed that cesarean delivery before the onset of labor may result in improved motor function, compared with delivery after the onset of labor, either by CS or vaginal. However, Bensen et al. [19], as well as studies conducted later [20, 21], found no benefits of CS compared with vaginal delivery for infants with MMC.

Recent studies from 2011 showed that there was no clinical evidence that early neurological outcome of MMC infant was improved by CS. Cuppen et al. [22] demonstrated that early neurological outcome was better in vaginally delivered infants than in those delivered by CS. Our conclusions are similar: more infants who were delivered vaginally had higher Apgar scores and were classified into the 3HS and $4 \mathrm{HS}$ groups; whereas infants who were delivered by $\mathrm{CS}$ had lower Apgar scores and were classified into the $1 \mathrm{HS}$ and $2 \mathrm{HS}$ groups. This means that those children who had a worse future motor condition were delivered by CS more often than children who had better future mobility. Merrill et at. [21] found that there were no significant differences by route of delivery for gestational age and birth weight. We found that children who were delivered by CS had lower birth weight and gestational age. The differences may be caused by a smaller group of children in the study by Merrill et al., as well as may be due to early indications for CS because of MMC severity.

All HS groups differed in anthropometric parameters at birth: weight and length. We found that birth length seemed to be one of the predicting factors of the future mobility of MMC children. Those who were classified into the $1 \mathrm{HS}$ 
group had lower birth lengths in contrast to the $4 \mathrm{HS}$ group. Children did not vary in gestational age.

In our study, we used the WHO Z-score to assess our patients' anthropometric measures. Z-scores are recommended as a sufficient statistical tool to assess children's physical development. However, we wonder if Z-scores are appropriate to use on children with congenital developmental disorders such as MMC. This aspect has yet to be studied. Moreover, Z-scores, as standardized quantities, are calculated based on the distribution of the reference population. There is a question if they are comparable across different countries and different populations of children. Of course, there is a need for further studies and refinements due to MMC.

This survey had some limitations. Firstly, we were not able to obtain information about the MMC children's moth- ers' health condition and socioeconomic status. Secondly, we did not obtain very detailed data about our patients' mothers' diets, folic acid, and other supplementation status, or applied treatment during pregnancy and during delivery. Finally, when interpreting our findings, it should be kept in mind that the sample size of our study was small.

\section{Conclusions}

1. Perinatal factors have a significant effect on children's physical activity.

2. There is no clinical evidence that cesarean section improves early neurological outcome of MMC infants.

3. Parental factors, especially maternal age, do not determine the future mobility of children with myelomeningocele.

Source of funding: This work was funded by the statutory grant no. N/ST/ZB/15/008/1141 (153-41763L).

Conflict of interest: The authors declare no conflict of interests.

\section{References}

1. Chang CK, Wong TT, Huang BS, et al. Spinal dysraphism: a cross-sectional and retrospective multidisciplinary clinic-based study. J Chin Med Assoc 2008; 71(10): 502-508.

2. Okurowska-Zawada B, Kozerska A, Żelazowska B, et al. Serum 25-hydroxyvitamin D, osteocalcin, and parathormone status in children with meningomyelocele. Neuropediatrics 2012; 43(6): 314-319.

3. Pauly M, Cremer R. Levels of mobility in children and adolescents with spina bifida-clinical parameters predicting mobility and maintenance of these skills. Eur J Pediatr Surg 2013; 23(2): 110-114.

4. Au KS, Ashley-Koch A, Northrup H. Epidemiologic and genetic aspects of spina bifida and other neural tube defects. Dev Disabil Res Rev 2010; 16(1): 6-15.

5. Frey L, Hauser WA. Epidemiology of neural tube defects. Epilepsia 2003; 44(Suppl. 3): 4-13.

6. Greene ND, Stanier P, Copp AJ. Genetics of human neural tube defects. Hum Mol Genet 2009; 18(2): R113-R129.

7. Shinde DN, Elmer DP, Calabrese P, et al. New evidence for positive selection helps explain the paternal age effect observed in achondroplasia. Hum Mol Genet 2013; 22(20): 4117-4126.

8. Hoffer MM, Feiwell E, Perry R, et al. Functional ambulation in patients with myelomeningocele. J Bone Joint Surg 1973; 55(1): 137-148.

9. Goldberg MF, Edmonds LD, Oakley GP. Reducing birth defect risk in advanced maternal age. JAMA 1979; 242(21): $2292-2294$.

10. Croen LA, Shaw GM. Young maternal age and congenital malformations: a population-based study. Am J Public Health 1995; 85(5): 710-713.

11. Reefhuis J, Honein MA. Maternal age and non-chromosomal birth defects, Atlanta, 1968-2000: teenager or thirty-something, who is at risk? Birth Defects Res A Clin Mol Teratol 2004; 70(9): 572-579.

12. Baird PA, Sadovnick AD, Yee IM. Maternal age and birth defects: a population study. Lancet 1991; 337(8740): 527-530.

13. Savva GM, Walker K, Morris JK. The maternal age-specific live birth prevalence of trisomies 13 and 18 compared to trisomy 21 (Down syndrome). Prenat Diagn 2010; 30(1): 57-64.

14. Vieira AR, Castillo Taucher S. Maternal age and neural tube defects: evidence for a greater effect in spina bifida than in anencephaly. Rev Med Chil 2005; 133(1): 62-70.

15. Gill SK, Broussard C, Devine O, et al. National Birth Defects Prevention Study. Association between maternal age and birth defects of unknown etiology: United States, 1997-2007. Birth Defects Res A Clin Mol Teratol 2012; 94(12): 1010-1018.

16. Vieira AR. Birth order and neural tube defects: a reappraisal. J Neurol Sci 2004; 217(1): 65-72.

17. Shurtleff DB, Luthy DA, Benedetti TJ, et al. The outcome of pregnancies diagnosed as having a fetus with meningomyelocele. Z Kinderchir 1987; 42(Suppl. 1): 50-52.

18. Luthy DA, Wardinsky T, Shurtleff DB, et al. Cesarean section before the onset of labor and subsequent motor function in infants with meningomyelocele diagnosed antenatally. N Engl J Med 1991; 324(10): 662-666.

19. Bensen JT, Dillard RG, Burton BK. Open spina bifida: does cesarean section delivery improve prognosis? Obstet Gynecol 1988; 71(4): 532-534.

20. Sakala EP, Andree I. Optimal route of delivery for meningomyelocele. Obstet Gynecol Surv 1990; 45(4): $209-212$.

21. Merrill DC, Goodwin P, Burson JM, et al. The optimal route of delivery for fetal meningomyelocele. Am J Obstet Gynecol 1998; 179(1): 235-240.

22. Cuppen I, Eggink AJ, Lotgering FK, et al. Influence of birth mode on early neurological outcome in infants with myelomeningocele. Eur J Obstet Gynecol Reprod Biol 2011; 156(1): 18-22.

Address for correspondence:

Dr n. med. Agata Korzeniecka-Kozerska

Klinika Pediatrii i Nefrologii

Uniwersytet Medyczny

ul. Waszyngtona 17, 15-274 Białystok

Tel.: +48 857 450-663

E-mail: agatakozerska@poczta.onet.pl 